\title{
HUBUNGAN KADAR GULA DARAH TIDAK TERKONTROL DAN LAMA MENDERITA DIABETES MELITUS DENGANFUNGSI KOGNITIF PADA SUBYEK DIABETES MELITUS TIPE 2
}

\author{
${ }^{1}$ Monica L. Meloh \\ ${ }^{2}$ Karel Pandelaki \\ ${ }^{2}$ Cerelia Sugeng
}

\author{
${ }^{1}$ Kandidat Skripsi Fakultas Kedokteran Universitas Sam Ratulangi Manado \\ ${ }^{2}$ Bagian Ilmu Penyakit Dalam BLU RSU Prof. Dr. R. D. Kandou Manado \\ Email:monica_meloh@yahoo.com
}

\begin{abstract}
Diabetes Mellitus (DM) type 2 is one of the chronic disease which related to the increased risk of cognitive decline. Uncontrolled blood glucose levels and duration of DM affect the pathophysiology of the occurrence of cognitive function disruption to DM type 2 subject. Uncontrolled blood glucose levels is HbA1c levels > 7\% and cognitive function measured by using Mini Mental State Examination (MMSE). The objective of this research is to find out the relation between an uncontrolled blood glucose levels and duration of DM to cognitive function from DM type 2 subject. Methods: This research is descriptive analytic with cross sectional approach. The sampling technique used was consecutive sampling. Result: The discoveries from all the 36 samples are a mean age of 55.2; length of sustaining DM 9.0; HbA1c 9.9; and MMSE score 24.7. Pearson correlation test results obtained the relation of HbA1c with MMSE score $(\mathrm{p}=0,215 ; \mathrm{r}=-0,212)$ and the relation of the duration of sustaining DM with MMSE score $(p=0,237 ; r=-0,202)$. Conclusion: There is a negative connection between uncontrolled blood sugar level and the duration of sustaining DM with cognitive function but statistically both of them are not significant to the DM type 2 subject.

Keywords: diabetes mellitus, HbA1c, length of sustaining DM, cognitive function.
\end{abstract}

\begin{abstract}
Abstrak: Diabetes Melitus (DM) tipe 2 adalah salah satu penyakit kronis yang berhubungan dengan peningkatan risiko penurunan kognitif. Kadar gula darah yang tidak terkontrol dan lama menderita DM, mempengaruhi patofisiologi terjadinya gangguan fungsi kognitif pada subyek DM tipe 2. Kadar gula darah yang tidak terkontrol adalah kadar HbA1c $>7 \%$ dan fungsi kognitif diukur berdasarkan Mini Mental State Examination (MMSE). Tujuan penelitian ini untuk mengetahui hubungan kadar gula darah yang tidak terkontrol dan lama menderita DM dengan fungsi kognitif subyek DM tipe 2. Metode: Penelitian ini bersifat deskriptif analitik dengan pendekatan cross sectional. Teknik pengambilan sampel yang digunakan yaitu consecutive sampling. Hasil: Dari 36 sampel didapatkan rerata usia 55,2; lama menderita DM 9,0; HbA1c 9,9; dan skor MMSE 24,7. Hasil uji korelasi pearson didapatkan hubungan HbA1c dengan skor MMSE ( $\mathrm{p}=0,215 ; \mathrm{r}=-0,212$ ) dan hubungan lama menderita DM dengan skor MMSE $(\mathrm{p}=0,237 ; \mathrm{r}=-0,202)$. Simpulan: Terdapat hubungan negatif antara kadar gula darah tidak terkontrol dengan fungsi kognitif dan terdapat hubungan negatif antara lama menderita DM dengan fungsi kognitif namun secara statistik keduanya tidak bermakna pada subyek DM tipe 2.
\end{abstract}

Kata kunci: diabetes melitus, HbA1c, lama menderita DM, fungsi kognitif. 
Diabetes melitus (DM) merupakan suatu kelompok penyakit metabolik dengan karakteristik hiperglikemia yang terjadi karena kelainan sekresi insulin, kerja insulin, atau kedua-duanya. ${ }^{1}$ Berbagai penelitian epidemiologi menunjukkan adanya kecenderungan peningkatan angka insidensi dan prevalensi DM tipe 2 di seluruh dunia, sekitar 90\% kasus. World Health Organization (WHO) memprediksi adanya peningkatan jumlah penyandang diabetes yang cukup besar pada tahuntahun mendatang. ${ }^{2}$ Riset Kesehatan Dasar (Riskesdas) melaporkan pada tahun 2013 terdapat 2,4\% kejadian DM di Indonesia. Prevalensi berdasarkan diabetes yang terdiagnosis, tertinggi terdapat di Yogyakarta (2,6\%), Jakarta (2,5\%), Sulawesi Utara (2,4\%) dan Kalimantan Timur (2,3\%). Prevalensi berdasarkan diabetes yang terdiagnosis dokter atau gejala, tertinggi terdapat di Sulawesi Tengah (3,7\%), Sulawesi Utara (3,6\%), Sulawesi Selatan (3,4\%) dan Nusa Tenggara Timur 3,3\%. ${ }^{3}$

DM tipe 2 adalah salah satu penyakit kronis yang berhubungan dengan peningkatan risiko penurunan kognitif dan demensia. ${ }^{4}$ Bila gejala penurunan kognitif dapat dikenali lebih awal maka dapat dilakukan upaya-upaya untuk meningkatkan atau mempertahankan fungsi kognitif agar tak jatuh dalam keadaan demensia. ${ }^{5}$ Beberapa faktor utama yang mempengaruhi hubungan antara diabetes melitus dan disfungsi kognitif, antara lain: aterosklerosis, penyakit mikrovaskular, advanced protein glycation dan stres oksidatif akibat toksisitas glukosa; dan insufficient insulin action sedangkan faktor lain yang mempengaruhi adalah penuaan, genetik dan penyakit penyerta seperti hipertensi, dislipidemia. ${ }^{6}$ Gangguan glukosa darah, seperti hiperglikemia dan hipoglikemia menjadi penyebab utama terjadinya gangguan kognitif pada subyek diabetes. Selain hiperglikemia dan hipoglikemia, gangguan insulin seperti resistensi insulin dan insufisiensi insulin, telah terbukti menyebabkan penurunan fungsi kognitif. ${ }^{7}$ Lama menderita DM dan tingkat keparahan yang diukur dari jenis pengobatan dan komplikasi diabetes, bisa menjadi hal penting dalam mempengaruhi patofisiologi terjadinya gangguan fungsi kognitif pada subyek diabetes. Sebaliknya, late onset of diabetes, menderita diabetes dalam jangka pendek, atau diabetes yang terkendali dengan baik, memilik dampak yang lebih rendah terhadap gangguan fungsi kognitif. ${ }^{8}$

Dalam mendiagnosis subyek DM, terdapat empat kriteria untuk menegakkan diagnosis, yaitu pemeriksaan kadar glukosa plasma sewaktu, kadar glukosa plasma puasa, kadar glukosa plasma 2 jam pada Test Toleransi Glukosa Oral (TTGO) dan pemeriksaan hemoglobin-glikosilat A1c (HbA1c). ${ }^{1}$ Pemeriksaan HbA1c merupakan pemeriksaan yang menjadi tolak ukur paling tepat dalam pengendalian DM. HbA1c dapat digunakan sebagai tes diagnostik untuk diabetes yang menunjukkan jaminan tes yang berkualitas dan sesuai dengan standar kriteria nilainilai rujukan internasional. ${ }^{9}$ Pemeriksaan HbA1c merupakan gold standard dalam pengukuran kadar glikemik bahkan pada orang non-diabetes yang terkait dengan kinerja kognitif dan volume otak. ${ }^{4}$ Kontrol gula darah merupakan dasar dari pengelolaan diabetes. $^{10}$

Instrumen untuk mengkaji atau alat bantu untuk penapisan gangguan fungsi kognitif dipergunakan skor Mini Mental State Examination (MMSE). ${ }^{11}$ Mini Mental State Examination adalah salah satu tes yang sering digunakan dalam pengobatan klinis untuk menilai fungsi kognitif subyek secara keseluruhan, secara signifikan terhadap memori dan perhatian. ${ }^{12,13}$ Pemeriksaan MMSE memiliki keuntungan waktunya cepat (5-10 menit) dan mudah dikerjakan serta dapat digunakan untuk memonitor perubahan dan perkembangan fungsi kognitif. Status kognitif pada orang dewasa yang lebih tua dapat mengidentifikasi perubahan awal dalam status fisiologis, kemampuan untuk belajar dan mengevaluasi respon subyek terhadap pengobatan juga menilai kemampuan fungsi kognitif yang berhubungan dengan 
aktivitas sehari -hari. ${ }^{12,14}$ Pengukuran fungsi kognitif dengan MMSE meliputi orientasi waktu dan tempat, registrasi, konsentrasi, ingatan jangka pendek, penamaan benda yang familiar, pengulangan ekspresi, dan kemampuan membaca dan mengikuti instruksi tertulis, menulis kalimat, menggambar, dan mengikuti tiga perintah lisan. ${ }^{14}$

\section{METODE PENELITIAN}

Jenis penelitian yang dilakukan bersifat deskriptif analitik dengan pendekatan cross sectional. Penelitian dilaksanakan pada bulan NovemberDesember 2014. Populasi penelitian adalah subyek DM tipe 2 yang berobat di poliklinik Endokrin Metabolik RSUP Prof.Dr.dr.R.D.Kandou Manado. Subyek penelitian adalah populasi terjangkau yang memenuhi kriteria inklusi dan eksklusi. Kriteria inklusi meliputi subyek DM tipe 2, kadar HbA1c > 7\%, usia 30-60 tahun, lama menderita $\mathrm{DM} \geq 5$ tahun dan bersedia ikut dalam penelitian dengan menandatangani (informed consent). Kriteria ekslusi meliputi subyek DM tipe 2 yang menderita stroke, anemia, gangguan psikiatri, tidak dapat mendengar dan berbicara.Sampel penelitian berjumlah 36 orang serta dipilih dengan cara consecutive sampling. Variabel yang digunakan untuk variabel bebas kadar HbA1c > 7 mg/dL dan lama DM ; variabel tergantung skor MMSE. Analisis data adalah analisis univariat dan bivariat dengan menggunakan uji statistik korelasi dengan bantuan komputer program SPSS versi 21.

\section{HASIL PENELITIAN}

Penelitian ini dilaksanakan dalam rentang waktu 2 bulan, selama periode bulan November - Desember 2014 di poliklinik Endokrin Metabolik RSUP Prof.Dr.R.D.Kandou Manado. Penelitian ini dilakukan secara observasional cross sectional terhadap 36 orang responden DM tipe 2 terhadap HbA1c dan gangguan kognitif yang datang berobat dengan menggunakan consecutive sampling.
Penelitian ini bertujuan untuk melihat hubungan kadar gula darah yang tidak terkontrol dan lama menderita DM dengan fungsi kognitif pada subyek diabetes melitus tipe 2. Untuk menentukan kadar gula darah yang tidak terkontrol dilakukan pemeriksaan HbA1c, menentukan lama menderita DM dilakukan anamnesis dan juga untuk menentukan fungsi kognitif digunakan tes MMSE.

Karakteristik Sampel Penelitian

Tabel 1. Karakteristik Sampel Penelitian

\begin{tabular}{cccccc}
\hline $\begin{array}{c}\text { Karakteristi } \\
\mathrm{k}\end{array}$ & $\mathrm{N}$ & Min & Maks & Rerata & SB \\
\hline $\begin{array}{c}\text { Usia } \\
\text { (tahun) }\end{array}$ & 36 & 34 & 60 & 55,2 & 4,4 \\
$\begin{array}{c}\text { Lama DM } \\
\text { tipe 2 } \\
\text { (tahun) }\end{array}$ & 36 & 5 & 30 & 9,0 & 5,9 \\
$\begin{array}{c}\text { HbA1c } \\
\text { Skor }\end{array}$ & 36 & 7,1 & 14,4 & 9,9 & 2,1 \\
$\begin{array}{c}\text { MMSE } \\
\text { MbS }\end{array}$ & 11 & 30 & 24,7 & 0,6 \\
\hline
\end{tabular}

Ket $: \mathrm{N}=$ jumlah sampel penelitian, $\min =$ minimum, maks $=$ maksimal, $\mathrm{SB}=$ Simpangan Baku

Berdasarkan Tabel 1, hasil menunjukkan bahwa sampel berjumlah 36 orang dengan usia termuda 34 tahun dan tertua 60 tahun memiliki rata-rata 55,2. Dari 36 sampel terbaru menderita DM adalah 5 tahun dengan terlama yaitu 30 tahun, memiliki nilai rata-rata yaitu 9,1 dengan simpangan baku sebesar 5,9. Nilai HBA1c terendah adalah 7,1 $\mathrm{mg} / \mathrm{dl}$ sedangkan nilai HBA1c tertinggi adalah 14,4 mg/dl, kadar HBA1c rata-rata sebesar 9,9 mg/dl dengan simpangan baku sebesar 2,1. Skor MMSE terendah yaitu 11 danskor MMSE tertinggi adalah 30, skor rata-rata adalah 24,7 dengan simpangan baku adalah 3,8 . 
Distribusi DM tipe 2 berdasarkan jenis kelamin

Tabel 2. Distribusi Sampel berdasarkan Jenis Kelamin

\begin{tabular}{ccc} 
Jenis Kelamin & $\mathrm{N}$ & Persentase \\
\hline Laki-laki & 22 & $61,1 \%$ \\
Perempuan & 14 & $38,9 \%$ \\
\hline Total & 36 & $100 \%$ \\
\hline
\end{tabular}

Berdasarkan tabel 2, hasil menunjukkan bahwa 22 orang subyek penelitian berjenis kelamin laki-laki dengan presentasi $61,1 \%$ dan 14 orang subyek penelitian berjenis kelamin perempuan dengan presentasi 38,9\% dari 36 sampel.

Tabel 3. Hubungan antara kadar HbA1c $>7$ dengan Skor MMSE

\begin{tabular}{ccc}
\hline Variabel & $\begin{array}{c}\text { Koefisien } \\
\text { Korelasi }\end{array}$ & Kemaknaan \\
\hline $\begin{array}{c}\text { HBA1C } \\
\text { MMSE }\end{array}$ & $\mathrm{r}=-0,212$ & $\mathrm{p}=0,215$ \\
\hline
\end{tabular}

Ket : Uji Korelasi Pearson

Hasil uji hubungan antara kadar HbA1c > 7 dengan skor MMSE, yang diuji dengan Uji Korelasi Pearson menyatakan ada hubungan negatif antara kadar HbA1c $>7$ dan skor MMSE namun secara statistik tidak bermakna $(\mathrm{p}=0,215 ; \mathrm{r}=-0,212)$ (Tabel $3)$.

Tabel 4. Hubungan antara lama menderita DM dengan Skor MMSE (Uji korelasi Pearson)

\begin{tabular}{ccc}
\hline Variabel & $\begin{array}{c}\text { Koefisien } \\
\text { Korelasi }\end{array}$ & Kemaknaan \\
\hline LAMA & & \\
DM $*$ & $r=-0,202$ & $p=0,237$ \\
MMSE & & \\
\hline
\end{tabular}

Tabel 4. Hasil uji hubungan antara lama menderita DM dengan skor MMSE, yang diuji dengan Uji Korelasi Pearson menyatakan ada hubungan negatif antara lama menderita DM dengan skor MMSE namun secara statistik tidak bermakna $(\mathrm{p}=0,237 ; \mathrm{r}=-0,202)$.

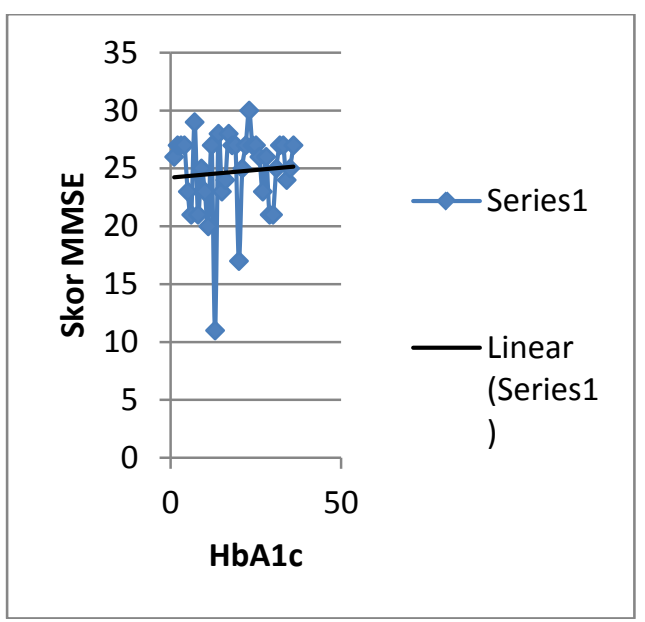

Gambar 1. Hubungan antara kadar HbA1c > 7\% dengan Skor MMSE

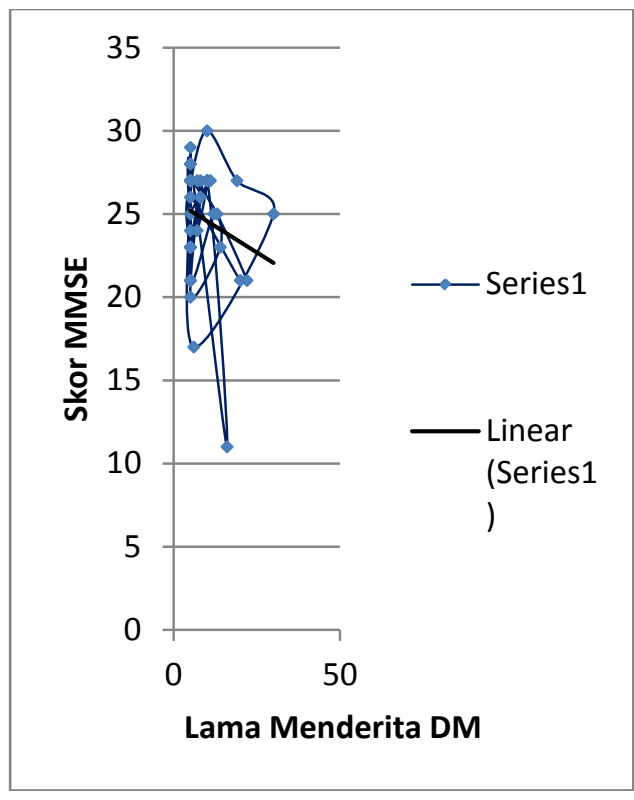

Gambar 2. Hubungan antara lama menderita DM dengan Skor MMSE

\section{BAHASAN}

Kontrol kadar gula darah mempunyai peran dalam menentukan derajat gangguan fungsi kognitif pada subyek DM tipe 2. Penelitian Takahiko Kawamura dkk melaporkan bahwa kontrol 
glukosa yang memburuk dapat menyebabkan memburuknya fungsi kognitif pada subyek. ${ }^{7}$

Berdasarkan hasil uji korelasi, didapatkan tidak ada hubungan yang bermakna antara kadar HbA1c dengan skor MMSE $(p=0,215 ; r=-0,212)$ dan lama menderita DM dengan skor MMSE ( $p=0,237 ; r=-0,202)$. Hasil yang didapatkan berbeda dengan penelitian yang dilakukan Takahiko Kawamura dkk dimana terdapat hubungan yang progresif dalam mempengaruhi penurunan fungsi kognitif. ${ }^{7}$

Faktor-faktor seperti penggunaan insulin, makanan tinggi karbohidrat, infeksi, penyakit, stress dan aktivitas dapat mempengaruhi kadar gula darah yang tidak terkontrol. Begitu juga dengan penurunan fungsi kognitif, dapat dipengaruhi oleh banyak faktor, diantaranya: Usia, hipoglikemia, resistensi insulin, defisiensi insulin, merokok, diet, exercise, stress, depresi, genetik, aterosklerosis, penyakit penyerta, dan dukungan keluarga.

Penelitian Beardlsey \& Goldstein pada tahun 1993, mendapatkan tingginya tingkat stress dapat dihubungkan dengan buruknya regulasi gula darah. Pada kondisi depresi, tubuh akan mengeluarkan hormonhormon stress yang akan mempengaruhi peningkatan kadar gula darah (HbA1c). ${ }^{15}$ Penelitian Kumar dkk pada tahun 2002, depresi dapat meningkatkan kerentanan terhadap dan / atau memperburuk defisit kognitif yang ada. Mekanisme neurobiologis yang tepat yang mendasari depresi dan kelainan kognitif pada diabetes tipe 2 tidak diketahui, penyakit mikrovaskuler yang mendasari terjadi komplikasi pada DM tipe 2 dan penyakit pembuluh darah telah diamati di antara orang dewasa yang lebih tua dengan depresi berat. ${ }^{16}$ Penelitian Watari dkk pada tahun 2006, tidak terdapat hubungan antara HbA1c dengan fungsi kognitif terhadap subyek depresi, hal ini mengindikasikan bahwa kontrol gula darah tidak berkorelasi terhadap fungsi kognitif. ${ }^{17}$

Berdasarkan data yang diperoleh subyek DM tipe 2 dengan usia termuda 34 tahun dan tertua 60 tahun memiliki rata- rata 55,2. Hal ini berbeda dengan penelitian Huang dkk pada tahun 2012, melaporkan bahwa HbA1c yang tinggi berhubungan dengan memori yang buruk pada usia 75 tahun ke atas. Hubungan antara HbA1c dengan memori dan bahasa menunjukkan hubungan yang positif seiring dengan bertambahnya usia. ${ }^{18}$ Penelitian Bruce dkk pada tahun 2008 melaporkan bahwa faktor resiko terjadinya demensia pada pasien berumur 70 ke atas adalah lama menderita dan aterosklerosis sedangkan HbA1c, kadar insulin dan hipertensi bukan merupakan faktor utama penyebab gangguan fungsi kognitif. $^{19}$

Penelitian The Action to Control Cardiovascular Risk in Diabetes (ACCORD) - Memory in Diabetes (MIND) yang dilakukan oleh Yaffe TC dkk pada tahun 2009 terhadap 10.251 subyek penderita DM tipe 2 dengan resiko tinggi penyakit kardiovaskuler menunjukkan bahwa terdapat hubungan antara kadar HbA1c yang tinggi dengan kognitif yang rendah. Kadar glukosa tinggi berhubungan dengan prevalensi faktor resiko penyakit kardiovaskuler dimana penyakit kardiovaskuler menjadi perantara terjadinya gangguan fungsi kognitif. ${ }^{20}$

Dukungan keluarga juga turut mempengaruhi kadar gula darah subyek DM tipe 2. Hasil penelitian yang dilakukan oleh Atyanti Isworo \& Saryono Saryono pada tahun 2010, terdapat hubungan yang signifikan antara hubungan dukungan keluarga dan kadar gula darah pada pasien DM tipe 2. Umur, pendidikan dan komplikasi juga menjadi faktor perancu dalam penelitian ini. ${ }^{21}$

Peneliti menyadari bahwa hasil penelitian ini masih memiliki banyak keterbatasan dan kekurangan. Peneliti tidak melakukan anamnesis lebih lengkap mengenai faktor-faktor yang dapat mempengaruhi fungsi kognitif pada subyek DM tipe 2. Diantaranya: penggunaan insulin, merokok, diet, exercise, genetik, dan penyakit penyerta yang diderita subyek. Dalam pemeriksaan fungsi kognitif dengan MMSE juga harus didampingi oleh dokter specialis atau yang lebih 
berpengalaman dalam melakukan pemeriksaan ini. Karena hasil dari pemeriksaan ini, sangat berpengaruh terhadap interpretasi fungsi kognitifnya.

\section{SIMPULAN}

Berdasarkan hasil penelitian dapat disimpulkan terdapat hubungan negatif antara kadar gula darah tidak terkontrol dengan fungsi kognitif dan terdapat hubungan negatif antara lama menderita DM dengan fungsi kognitif dengan nilai korelasi pearson berturut-turut $r=-0,212$ dan $r=-0,202$ namun secara statistik tidak bermakna pada subyek DM tipe 2 .

\section{DAFTAR PUSTAKA}

1. Perkumpulan Endokrinologi Indonesia. Konsensus Pengelolaan dan Pencegahan Diabetes Melitus Tipe 2 di Indonesia 2011. Jakarta: PB PERKENI; 2011.

2. Suyono S. Diabetes Melitus di Indonesia. Dalam: Sudoyo A W, Setiyohadi B, Alwi I, Simadibrata M, Setiati S, editors. Buku Ajar Ilmu Penyakit Dalam. Jilid III. Edisi kelima. Jakarta: Interna Publishing. 2009. p. 1875.

3. Riset Kesehatan Dasar 2013.

4. Ravona R-Springer, Heymann A, Schmeidler J, Moshier E, Godbold J, Sano M, et al. Trajectories in Glycemic Control over Time Are Associated with Cognitive Performance in Elderly Subjects with Type 2 Diabetes. Plos ONE.2014. doi: 10.1371/journal.pone.0097384.

5. Rochmah S, Hanmurti K. Demensia. In: Sudoyo Aru W, Setiyohadi B, Alwi I, Simadibrata M, Setiati S, editors. Buku Ajar Ilmu Penyakit Dalam. Jilid III. Edisi kelima. Jakarta: Interna Publishing. 2009; p. 837-44.

6. Biessels GJ, Staekenborg S, Brunner E, et al. Risk of dementia in diabetes mellitus: a systematic review. Lancet Neurol 2006; 5: 64-74.

7. Kawamura T, Umemura $T$, Hotta $N$. Cognitive impairment in diabetic patients: Can diabetic control prevent cognitive decline?. Journal of Diabetes Investigation
8. Roberts RO, Geda YE, Knopman DS, et al. Duration and Severity of Diabetes Are Associated with Mild Cognitive Impairment. Arch Neurol. Aug 2008; 65(8): 1066-1073. doi: 10.1001/archneur.65.8.1066.

9. Use of glycated haemoglobin (HbA1c) in the Diagnosis of diabetes mellitus:report of a WHO consultation. World Health Organization 2011.

10.Herman WH. Evidence-Based Diabetes Care. doi: 10.2337/diaclin.20.1.22 Clinical Diabetes January 2002 vol. 20 no. 1 22-23.

11. Martono HH. Gangguan kesadaran dan kognitif pada usia lanjut. Dalam:

Martono H, Pranarka K, editor. Edisi keempat. Buku Ajar Geriatri. Jakarta: Balai Penerbit FKUI.2010.

12.Budson AE, Price BH. Memory dysfunction in clinical practice. $\mathrm{N}$ Engl J Med, Suppementary Appendix, 2005.

13.Kipps CM, Hodges JR. Cognitive assesment for clinians. Neurol Neurosurg Psychiatry 2005;76(Suppl I):i22-i30. doi: 10.1136/jnnp.2004.059758.

14.Vertesi A, Lever J.A, Molloy D.W, et al. Standardized Mini Mental State Examination. Canadian Family Physician 2011;47:2018-2023.

15.Beardsley, G., \& Goldstein, M. G. (1993). Psychological factors affecting physical condition. Endocrine disease literature review. Psychosomatics, 34, 12-19.

16.Kumar, A., Mintz, J., Bilker, W., \& Gottlieb, G. (2002). Autonomous neurobiological pathways to late-life major depressive disorder: Clinical and pathophysiological implications. Neuropsychopharmacology, 26, 229236.

17.Watari K, Letamendi A, ElderkinThompson V, et al. Cognitive function in adults with type 2 diabetes and major depression. doi: 10.1016/j.acn.2006.06.014.

18.Huang J, Schmeidler J, Beeri MS, et al. Haemoglobin A1c and cognitive function in very old, cognitively intact men. Age Ageing (2012) 41 
Jurnal e-Clinic (eCl), Volume 3, Nomor 1, Januari-April 2015

(1):125-128. doi: 10.1093/ageing/afr124.

19.Bruce DG, Davis WA, Casey GP,et al.Predictors of cognitive impairment and dementia in older people with diabetes.Diabetologia2008; 51: 241248.

20. Yaffe CT, Gerstein HC, Williamson JD, et al. Relationship between baseline gycemic control and cognitive function in individuals with type 2 diabetes and other Cardiovascular risk factors. Diabetes care. Feb 2009;32(2): 221-226. doi: 10.2337/dc08-1153.

21. Isworo A, Saryono S. Hubungan Depresi dan Dukungan Keluarga terhadap Kadar Gula Darah pada Pasien Diabetes Melitus tipe 2 di RSUD Sragen. 2010 vol 5, No 1. 